\title{
OCCURRENCE OF ARTICHOKE LATENT POTYVIRUS (ARLV) AND TOMATO SPOTTED WILT VIRUS (TSWV) AS MIXED INFECTION IN ARTICHOKE PRODUCTION AREAS
}

\author{
FIDAN, H. ${ }^{*}{ }^{*}-$ KOÇ, G. ${ }^{2}$ \\ ${ }^{I}$ Plant Protection Department, Faculty of Agriculture, Akdeniz University, Antalya, Turkey \\ ${ }^{2}$ Subtropical Fruits Research and Experimental Center, Çukurova University, Adana, Turkey \\ *Corresponding author \\ e-mail: hakanfidantr@hotmail.com.tr
}

(Received $11^{\text {th }}$ Mar 2019; accepted $1^{\text {st }}$ May 2019)

\begin{abstract}
Artichoke (Cynara scolymus), is one of the most important agricultural products of North Cyprus (NC) due to its importance in export. During field surveys in artichokes production fields between 2013 and 2016, little and indistinguishable leaves, light shaded regions taking after mosaic with yellowish wilting of the leaves and little head development plants were gathered and broken down by DAS-ELISA for the examination of infections (most of them mentioned by Gallitelli et al. (2004)) which could be harmful to artichokes (belonging to groups of Nepovirus, Cheravirus, Fabavirus, Ilarvirus, Cucumovirus, Tombusvirus, Tobamovirus, Tobravirus, Potyvirus, Carlavirus, Potexvirus, Crinivirus, Tospovirus, Anulavirus, in the families of Rhabdoviridae and Bromoviridae respectively). Thirty-three samples were detected positive for mix infection of Artichoke Latent Potyvirus (ArLV) and Tomato spotted wilt virus (TSWV) in Laboratory assays (ELISA and RT-PCR). The results were also confirmed by RT-PCR using total RNA which was extracted from the leaves. RT-PCR assay was conducted by newly designed Sense and antisense primer pairs specific to ArLV; L1TSWVR and L2TSWVF primer pairs specific to TSWV. As results of RT-PCR, the region of 485 bp special to coat protein of ArLV and $276 \mathrm{bp}$ of TSWV were obtained in $2 \%$ agarose gel. While occurrence of remaining viruses was not detected in the tested samples, it was observed that disease incidence increased due to non-sterile equipment and devices during the harvest. Additionally, infected product materials, transmission with aphid and thrips vectors also increased disease incidence. In NC, the occurrence of ArLV was assigned as a new virus disease in Artichoke and also mixed infection with TSWV.
\end{abstract}

Keywords: Northern Cyprus, artichoke, RT-PCR, DAS-ELISA, ArLV, TSWV

\section{Introduction}

Artichoke (Cynara scolymus Linneus, 1753) is a financially essential vegetable. It is developed for its huge meaty juvenile inflorescences (capitula) that are broadly expended in both new and saved frame. Production is not confined to the Mediterranean region, yet additional export is needed in the Central East, North Africa, South America United States, and China (FAO, 2015). There are numerous components diminishing the amount and nature of artichoke production in different harvests. Plant viral diseases are amongst the most critical prohibitive components incorporating plant malady and irritations. Among the critical agronomic qualities, as a few maladies caused by infections have significant reproducing targets and have extraordinary monetary effect on artichoke generation around the world. Cucumber mosaic virus, Artichoke mottled crinkle virus, Tomato black ring virus, Artichoke Italian latent virus, Artichoke Aegean ringspot virus, Artichoke vein banding virus, Broad bean wilt virus, Tobacco streak virus, Artichoke yellow ringspot virus, Tobacco mosaic virus, Pelargonium zonate spot virus; Tobacco rattle virus; Artichoke latent virus, Bean yellow mosaic virus, Artichoke 
latent virus S, Turnip mosaic virus, Artichoke latent virus $\mathrm{M}$, an anonymous infection remotely related serologically to Poplar mosaic virus, Artichoke curly dwarf virus, Artichoke degeneration virus, Potato virus $X$, Tomato infectious chlorosis virus, Tomato spotted wilt virus have caused infections. Morphology, scientific categorization, symptomatology, cytopathology, the study of disease transmission, determination and sanitation of these Cynara tainting species (since 1950s) have been investigated by Gallitelli et al. (2004). Furthermore, Arabis Mosaic Virus, Alfalfa Mosaic Virus, Tomato Bushy Stunt Virus, Potygroup specific antisera and Potato Virus Y were also reviewed in Gallitelli et al. (2004).

Another Artichoke disease caused by Artichoke Yellow Ringspot Virus was first reported in Globe Artichoke in Turkey by Paylan et al. (2013). Same researchers also reported CMV in globe artichoke.

The ArLV is a potyvirus, which is able to transmit experimentally in non-persistent manner to artichoke seedlings by afid species (Aphis fabae, Myzus persicae and Brachycaudus cardui by Rana et al., 1982). Its first detection from symptomless globe artichoke plants was found in Tunisia by Marrou and Mehani (1964). Transmission efficiency was higher by the quick re-infection rate (over $75 \%$ in two years) registered in a field trial in Sardinia, Italy (Foddai et al., 1985). The C. syriaca and C. cardunculus species are not resistant to ArLV (Manzanares et al. (1995). The ArLV is responsible for reductions in plant thrive and blossom what is more, instigates misfortunes in the number and the heaviness of gathered plates running from 3 to 47\% (Pecaut et al., 1983; Foddai and Man-as, 1984; Migliori et al., 1987). Moreover, ArLV infection causes subjective and quantitative changes in 'Brindisino' artichoke, for example, leaf and bracts staining, opening of head peak, postponement of first reap, shortening of head stalk, decrease of head distance across and diminishing of yield (Rana et al., 1992).

This paper aims to decide the possibility and predictability of regular artichoke infections, incorporating ArLV in North Cyprus (NC) where presence of artichoke infections has not been investigated yet.

\section{Materials and methods}

The exploration was led in NC in 2013-2016 (Fig. 1). An aggregate of 97 tests were gathered from suspected plants in artichoke fields at various areas in the Island. Amid the overviews, little and indistinguishable leaves, light shaded zones looking like mosaic with yellowish shrinking of the leaves and little head development were seen on artichoke plants. Studies were directed amid the developing season and just symptomatic examples were gathered haphazardly all through the zone in the district.

\section{Serological tests}

The samples, were named and put in isolated plastic packs, conveyed to the Virology Lab by putting in ice pail and kept at $4{ }^{\circ} \mathrm{C}$. All examples were handled inside $24 \mathrm{~h}$.

\section{Double antibody sandwich enzyme linked immunosorbent assay (DAS-ELISA)}

For distinguishing proof infections contaminating artichoke, leaf tests were tried by DAS-ELISA utilizing polyclonal antiserum explicit to infections which has a place with gatherings of Nepovirus, Cheravirus, Fabavirus, Ilarvirus, Cucumovirus, Tombusvirus, Tobamovirus, Tobravirus, Potyvirus, Carlavirus, Potexvirus, Crinivirus, Tospovirus, in 
the families of Rhabdoviridae and Bromoviridae, which are given in Table 1, Each explicit antisera separately obtained from Agdia USA, Bioreba AG, Switzerland and Loewe ${ }^{\circledR}$ Biochemica GmbH, Germany.

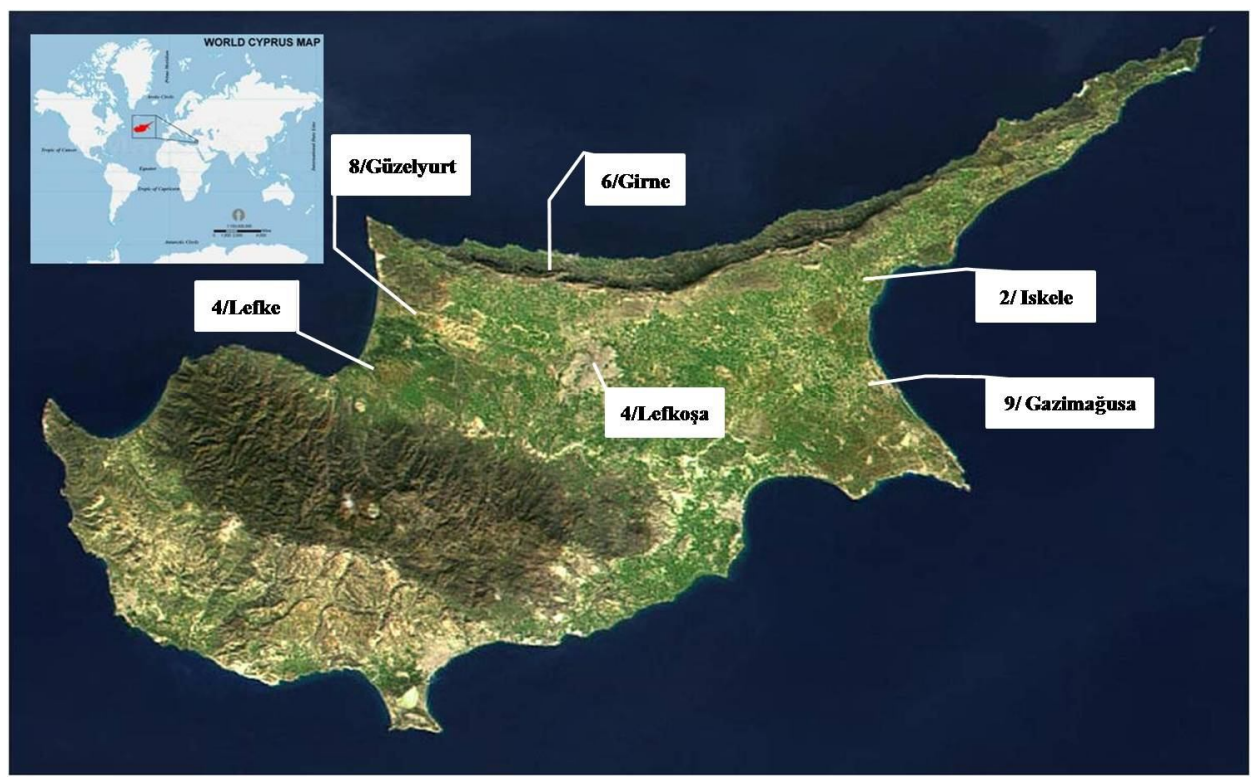

Figure 1. The map of Cyprus Island with positive locations (http://www.cyprusproperties.comcyprusgeography.htm; http://www.emapsworld.comcyprus-location-map.html, in small)

Tests included location of infections in tainted fresh leaves and conveyed by Clark and Adams (1977). Polystyrene microtiter plates were covered with 1:200 weakening of gamma globulin. The leaves of contaminated fresh explants were grounded in the extraction cradle (phosphate cushioned saline, PBS, $\mathrm{pH}$ 7.0). Plant tests were connected at a weakening of $1 / 5$ (Wff) in PBS (pH7.0), containing 0.05 volumes Tween-20, $0.2 \%$ polyvinyl pyrolidone (PVP-40) and $2 \%$ bovine serum albumin (BSA). IgG-conjugate was applied at the concentration of $1 \mathrm{ul} / 200 \mathrm{ul}$ (Agdia and Loewe) and $1 \mathrm{ul} / 1000 \mathrm{ul}$ (Bioreba). Alkaline phosphatase conjugate was utilized at a 1/1000 dilution.

Results were obtained spectrophotometrically at $405 \mathrm{~nm}$ wave length at Medispec ESR 200 ELISA microplate peruser. Additionally, negative controls (healthy samples), double the mean estimation of healthy sample were considered as positive. Positive controls of all infections were provided in lyophilized frame with the units and were resuspended in the examined support as prescribed by the manufacturer (Agdia, Inc.).

\section{Molecular analysis (phylogeny, total $R N A$ isolation and reverse-transcription polymerase chain reaction ( $R T-P C R)$}

Add up to RNA separates (Dellaporta et al., 1983) of ArLV and TSWV contaminated artichoke plants were utilized in a Reverse-Transcription Polymerase Chain Response (RT-PCR) with new sense (Forward primer) 5'-ATCTCGTGACGAAGCAACAA-3' and antisense (Reverse primer) 5'-CGAGACCATCGTGAATCTCC-5' primers, designed based on nucleotide sequences alignment of CP genes of diverse isolates Artichoke latent virus isolates, complete genome GenBank: KF155694.1 7163..7642 /product="CP protein"485 bp from NCBI via Primer-BLAST program and L1TSWVR 
and L2TSWVF specific to TSWV (Adkins et al., 2005). First and second strand cDNAs were blended from ArLV and TSWV RNAs utilizing Thermo Scientific Verso 1-Step RT-PCR Hot-Start Kit pack according to producer's convention. Enhancement for ArLV continued through a cycle of denaturation at $95{ }^{\circ} \mathrm{C}(45 \mathrm{~s})$, toughening at $55{ }^{\circ} \mathrm{C}$ (45 s.) and expansion at $72{ }^{\circ} \mathrm{C}(45 \mathrm{~s})$ for a sum of 35 cycles in Techne Genius thermal cycler. Steps mentioned above were utilized for TSWV likewise.

Table 1. Serologic and molecular studies and results of Cynara scolymus (artichoke) plant samples

\begin{tabular}{|c|c|c|c|}
\hline Virus Species & Plant species & Assays & *Result \\
\hline TBRSV (Tomato Black RingVirus) & Cynara scolymus & DAS-ELISA & - \\
\hline TSV (Tomato Streak Virus) & $"$ & DAS-ELISA & - \\
\hline TEV (Tobacco Etch Potyvirus) & $"$ & DAS-ELISA & - \\
\hline TuMV (Turnip Mosaic Potyvirus) & $"$ & DAS-ELISA & - \\
\hline WMV-2 (Watermelon Mosaic 2 Potyvirus) & $"$ & DAS-ELISA & - \\
\hline TBSV (Tomato Bushy Stunt Tombusvirus) & $"$ & DAS-ELISA & - \\
\hline ArMV (Arabis Mosaic Virus) & $"$ & DAS-ELISA & - \\
\hline CMV (Cucumber Mosaic Virus) & $"$ & DAS-ELISA & - \\
\hline PepMoV (Pepper Mottle Potyvirus) & $"$ & DAS-ELISA & - \\
\hline TMV (Tobacco Mosaic Virus) & $"$ & DAS-ELISA & - \\
\hline TRV (Tobacco Rattle Tobravirus) & $"$ & DAS-ELISA & - \\
\hline ToMV (Tomato Mosaic Virus) & $"$ & DAS-ELISA & - \\
\hline Tospo (Tospovirus) & $"$ & DAS-ELISA & + \\
\hline PVX $($ Potato Virus X) & $"$ & DAS-ELISA & - \\
\hline BCMV (Bean common mosaic potyvirus) & $"$ & DAS-ELISA & - \\
\hline Poty (Group Poty Virus) & $"$ & DAS-ELISA & + \\
\hline PVY (Potato Virus Y) & $"$ & DAS-ELISA & - \\
\hline AMV (Alfalfa Mosaic Virus) & $"$ & DAS-ELISA & - \\
\hline ZYMV (Zucchini Yellow Mosaic Virus) & $"$ & DAS-ELISA & - \\
\hline LMV (Lettuce mosaic potyvirus) & $"$ & DAS-ELISA & - \\
\hline LYSV (Leek yellow stripe potyvirus) & $"$ & DAS-ELISA & - \\
\hline OYDV (Onion yellow dwarf potyvirus) & " & DAS-ELISA & - \\
\hline TSWV (Tomato Spotted Wilt Virus) & $\begin{array}{c}\text { Cynara scolymus } \\
\text { Lycopersicon esculantum }\left(\mathbf{m i}^{*}\right) \\
\text { Capsicum annum }\left(\mathbf{m i} \boldsymbol{i}^{*}\right)\end{array}$ & $\begin{array}{c}\text { DAS-ELISA } \\
\text { RT-PCR }\end{array}$ & $\begin{array}{l}+ \\
+ \\
+\end{array}$ \\
\hline ArLV (Artichoke Latent Potyvirus) & $\begin{array}{c}\text { Cynara scolymus } \\
\text { Nicotiana clevelandii }\left(\mathbf{m i}^{*}\right) \\
\text { Chenopodium amaranticolor }\left(\mathbf{m i}^{*}\right)\end{array}$ & RT-PCR & $\begin{array}{l}+ \\
+ \\
+\end{array}$ \\
\hline
\end{tabular}

*(-) Negative (not infected); (+) Positive (infected); mi (mechanically inoculated)

\section{Analysis of RT-PCR products}

Ten microliters of the PCR reaction blend was joined with gel loading buffer and dissected on a $2 \%$ agarose gel containing $0.5 \mathrm{mg} / \mathrm{ml}$ of ethidium bromide and shot (Sambrook et al., 1989). 100 bp DNA stepping ladder (thermo) or Bio Marker TM Low (Bio Ventures, Inc.) were utilized on each gel to decide the length of the amplified item. 


\section{Phylogenetic analysis}

The RT PCR products were sequenced and dnasp5 program conducted for haplodisation analysis. Phylogeny performed by MEGA 7 software program and neighbor joining process, according to convention analysis.

\section{Mechanical inoculation}

Inoculation were processed when the first real leaves of seedlings appeared and approximately $15 \mathrm{~cm}$ in length. $1 \mathrm{~g}$ inoculum (Positive Samples via DAS-ELISA\&RTPCR) was added into $2 \mathrm{ml} 0.01 \% \mathrm{M}$ phosphate buffer solution with carborandum and silicon oxide. The mixture was prepared for mechanical inoculation, and was applied on the first real leaves of plants by hand etching. The temperature was kept at $22-24{ }^{\circ} \mathrm{C}$ and proportional humidity at $60-70 \%$ in test greenhouses (Garland et al., 2005).

\section{Results}

\section{Detection and occurrence of viruses by serology (ELISA)}

Positive results were obtained from Tospovirus groups, TSWV and Potyvirus. Tomato spotted wilt tospovirus (TSWV) is one of the unique member of Tospovirus. Orthotospoviruses or Tospoviruses are genera of negative RNA virus found within the Tospoviridae family of the Bunyavirales order (Lima et al. (2017)).

Assay results were given as positive reactions from samples against both TSWV and Tospovirus group specific antiserum.

Serological analyses were repeated at least two times to approve, 27 out of 33 positive samples also produced positive reaction with the potyvirus group specific antiserum. Samples of artichoke, were 33 positive, collected from six provinces, 6/Girne (Krynea), 8/Güzelyurt (Omorpho), 4/Lefke, 2/ Iskele (Trikomo), 4/Lefkoşa (Nicosea) and 9/ Gazimağusa (Famagusta) (Fig. 1). However, none of the PVY, BCMV, LMV, LYSV, OYDV, PepMoV, TEV, TuMV, WMV, ZYMV viruses has had positive reaction. ArLV member of the Potyvirus genus in the Potyviridae family have been previously reported in Artichoke worldwide (Gallitelli et al., 2004; Martelli and Gallitelli, 2008; Pasquini and Barba, 2003; Erkan et al., 2014; Fidan et al., 2015; Rana et al., 1982). Due to having positive result to Potyvirus group and non-absence of ArLV commercial antiserum, the test by RT-PCR is performed on the artichoke plants.

\section{Type of symptoms}

Virus tainted leaves with yellowish wilting in the fields have diminished in size and weight (Figs. 2 and 3). There is likewise, leaf twisting or distortion (Fig. 4), little head development and general staining were seen on the artichoke plants (Fig. 5). Amid head reaping, the plant heads were sliced from start of line to end of line. Rural workers have not changed or surface cleaned all types of cutting gear. Consequently, all collected artichokes have indicated extreme maladies (Fig. 3). This unmistakably shows that mechanical reaping will spread the infections. The symptoms from collected samples were similar with Spanò et al. (2018). 


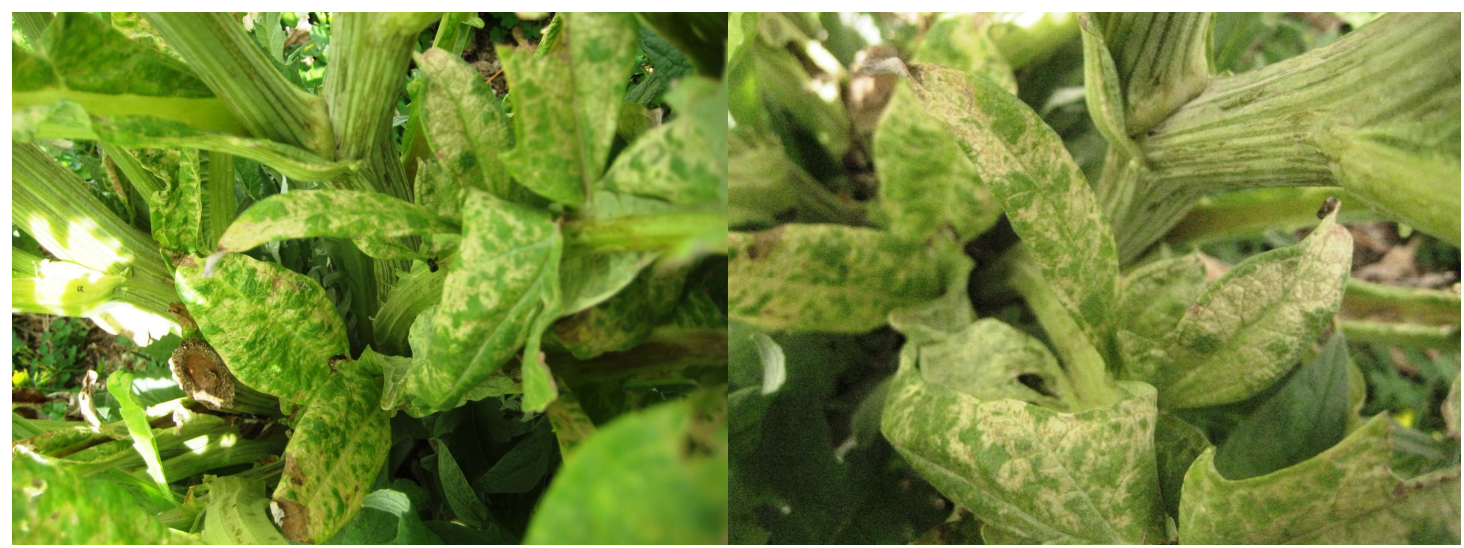

Figure 2. Chlorotic spots and mosaic on artichoke leaf induced by infected by ArLV $+T S W V$

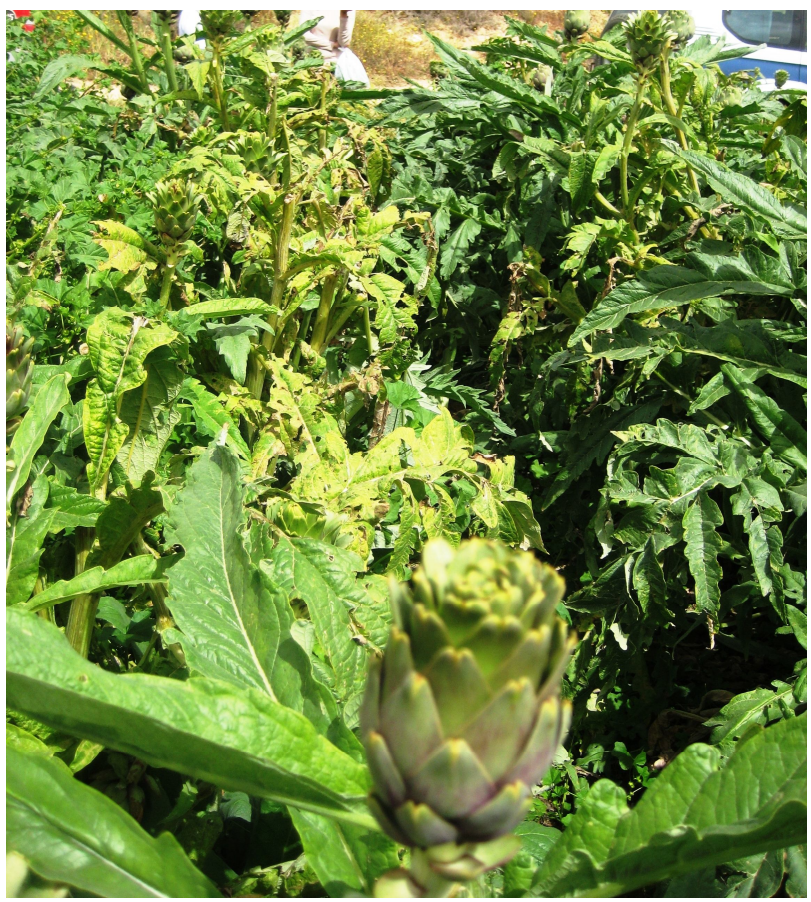

Figure 3. Yellowish withering of the leaves on infected plants

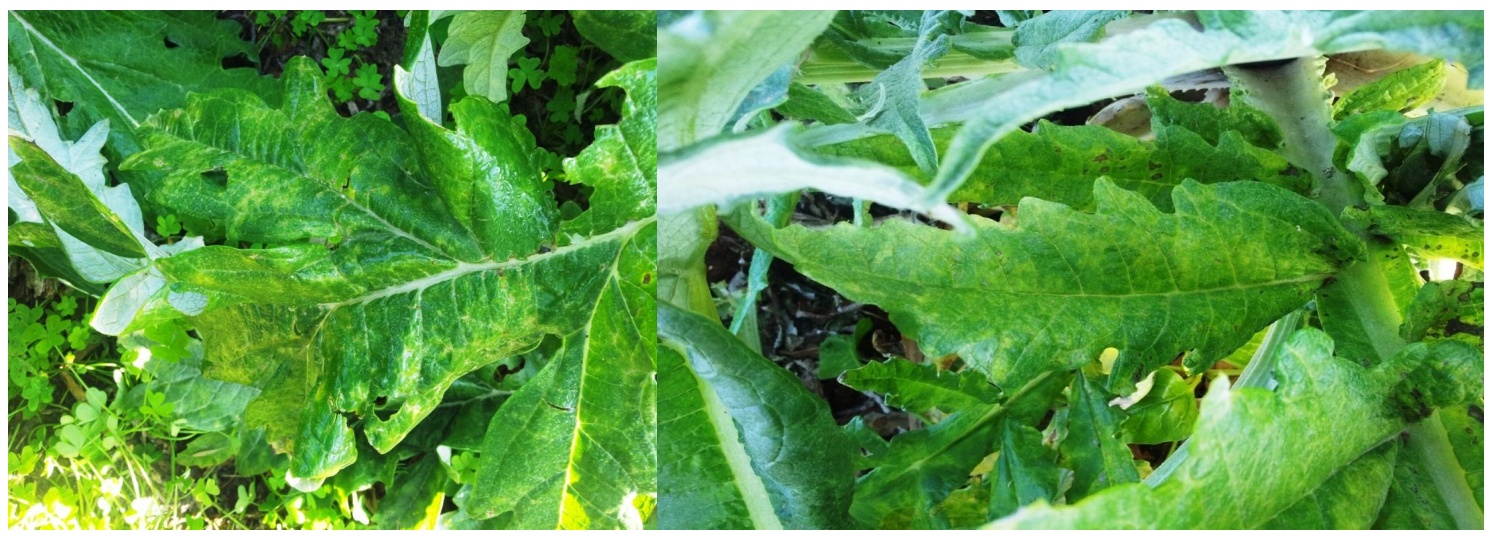

Figure 4. Leaf distortion, mosaic, necrosis spots on Artichoke induced by ArLV 


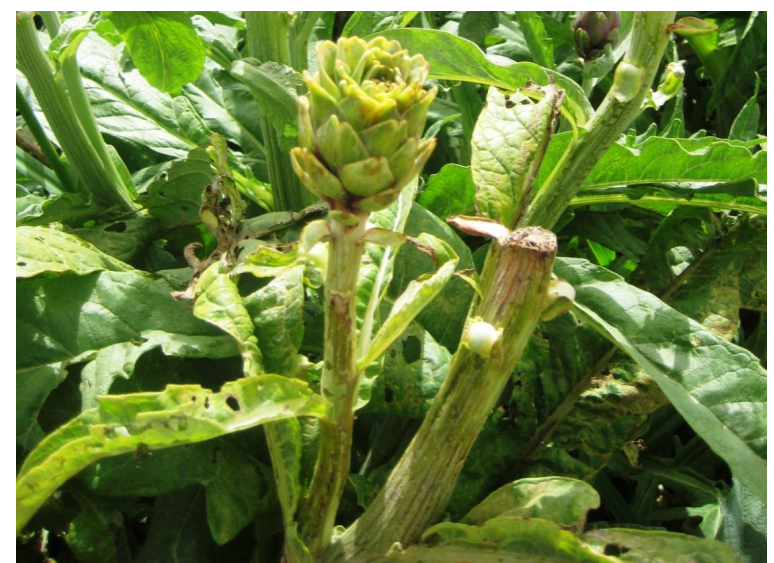

Figure 5. Small-head formation and general discoloration on artichoke plants

\section{Mechanical inoculation studies}

About 20 days after the date of mechanical inoculation, observations and investigations about the symptoms of diseases in tomato, pepper, tobacco and Chenopodium spp. plants have been conducted. At the end of the test, characteristic dark brown lesion, yellow concentric ring and necrotic spot, systemic mosaic and Necrotic local lesion symptoms via TSWV and ArLV were recorded between the leaf veins of sensitive plants (Figs. 6 and 7). Symptoms on assayed indicators were tested to confirm the infections in these plants by serologic and molecular based diagnosis.

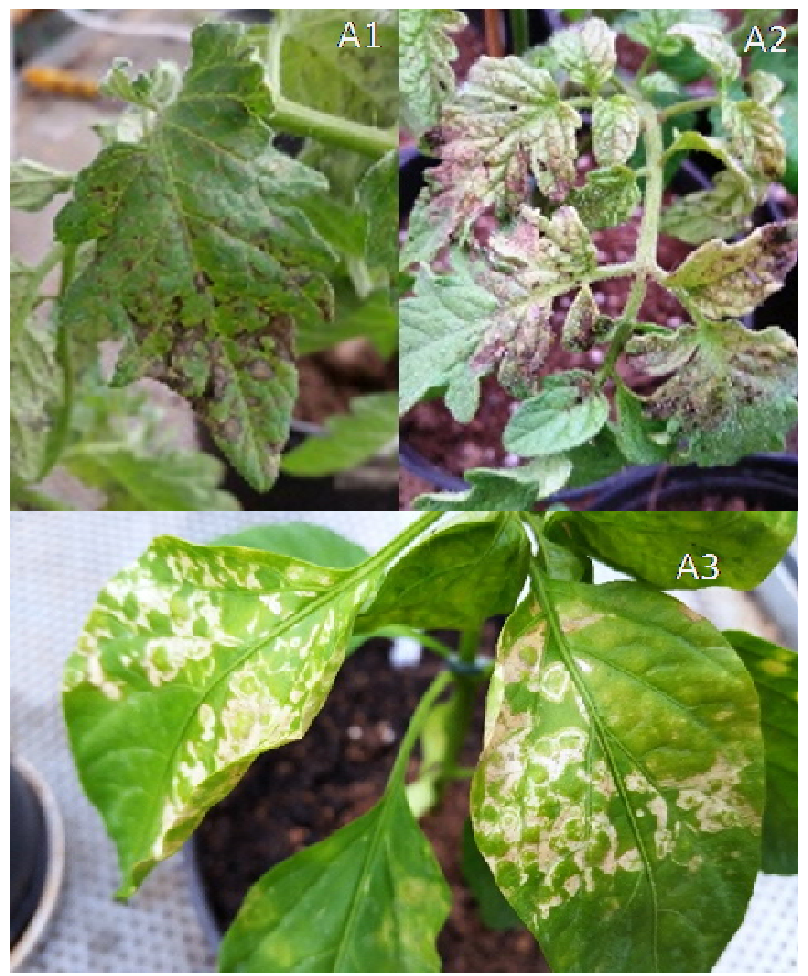

Figure 6. Dark brown lesions on Lycopersicon esculantum (A1-A2). Yellow concentric rings and necrotic spots on Capsicum annum (A3). (Mechanically inoculated by TSWV Artichoke Cyprus isolate) 


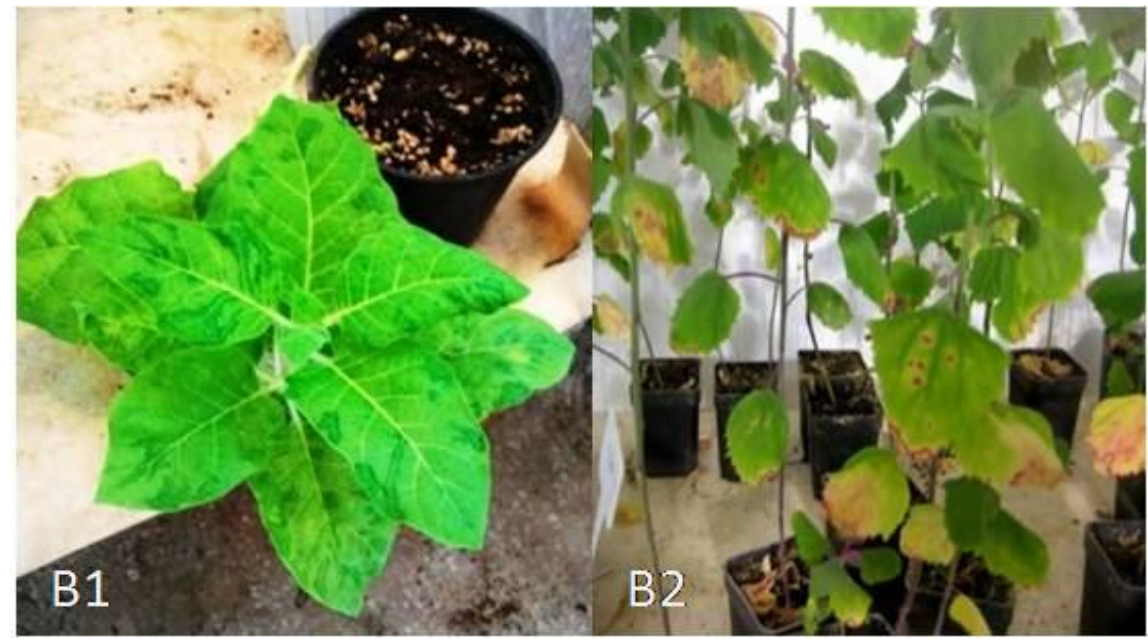

Figure 7. Severe systemic mosaics on Nicotiana clevelandii (B1). Necrotic local lesions on Chenopodium amaranticolor (B2). (Mechanically inoculated by ArLV Artichoke Cyprus isolate)

\section{The RT-PCR}

With the end goal to confirm the disease, RT-PCR examinations have intensified ArLV RNA, yielding an expected result of 485 bp (Fig. 8) on agarose gel (2\%) in all samples of artichoke. Subsequently, RT-PCR results affirmed that the diseases of ArLV in DAS-ELISA were positive for the plants. Furthermore, $276 \mathrm{bp}$ cDNA bands of TSWV were observed correspondingly (Fig. 9) in all examples. During the test, healthy plant material was used as negative control in order to eliminate plant misleading factors.

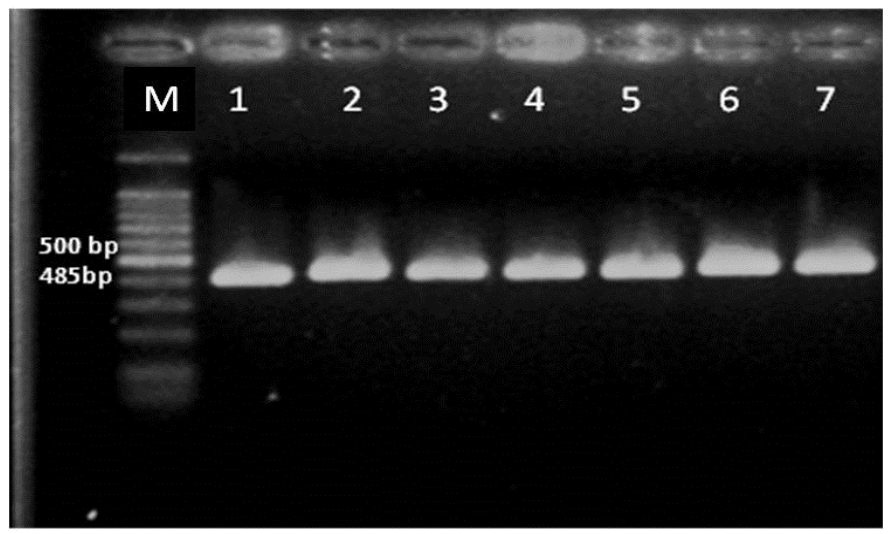

Figure 8. RT-PCR product of 485 bp of ArLV CP on agarose gel (2\%); DNA ladder (first lane M), Lane 1-3 samples positive of Artichoke in NC; Lane 4 positive control; Lane 5-7 samples positive of Artichoke in NC

\section{Phylogenetic analysis}

Phylogeny performed by MEGA 7 software program and neighbor joining process, according to conventional analysis for all ArLV isolates (Fig. 8). Two different haplotypes were determined from 7 isolates by RT-PCR and sequences. These two distinctive isolates were compared with each other and other known world's isolates. 


$$
-7687 \text { - }
$$

Their outcomes were submitted to NCBI framework as new records. The outcomes were cleared up that these two isolates have comparative homology with KF 155694.1 (99\%-Italy) and KP405233.1 (96\%-France) separately (Fig. 10).

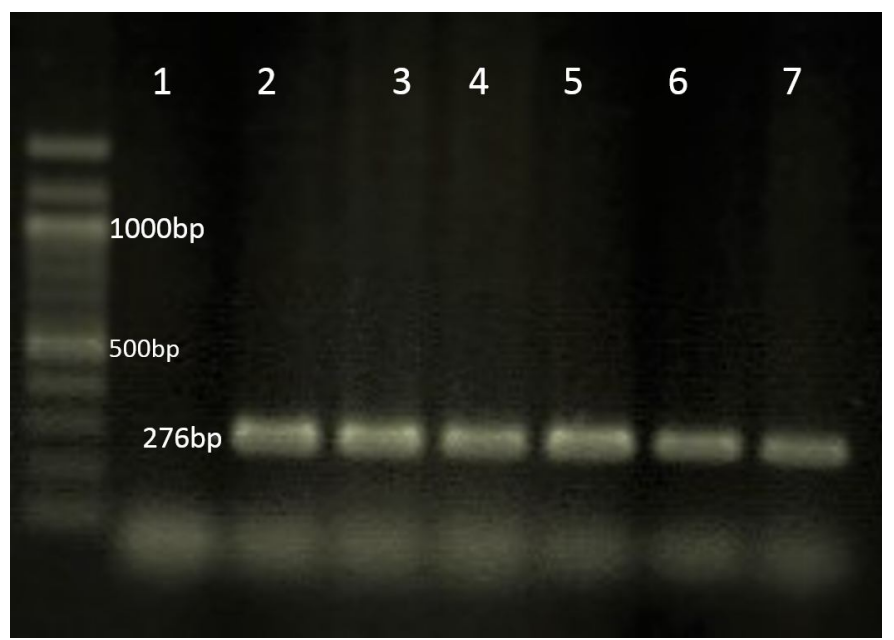

Figure 9. RT-PCR product of 276 bp of TSWV CP on agarose gel (2\%); DNA ladder (First lane $M)$, Lane 1 negative control; Lane 2 positive control (TSWV infected pepper); Lane 3-7 positive samples of Artichoke in NC

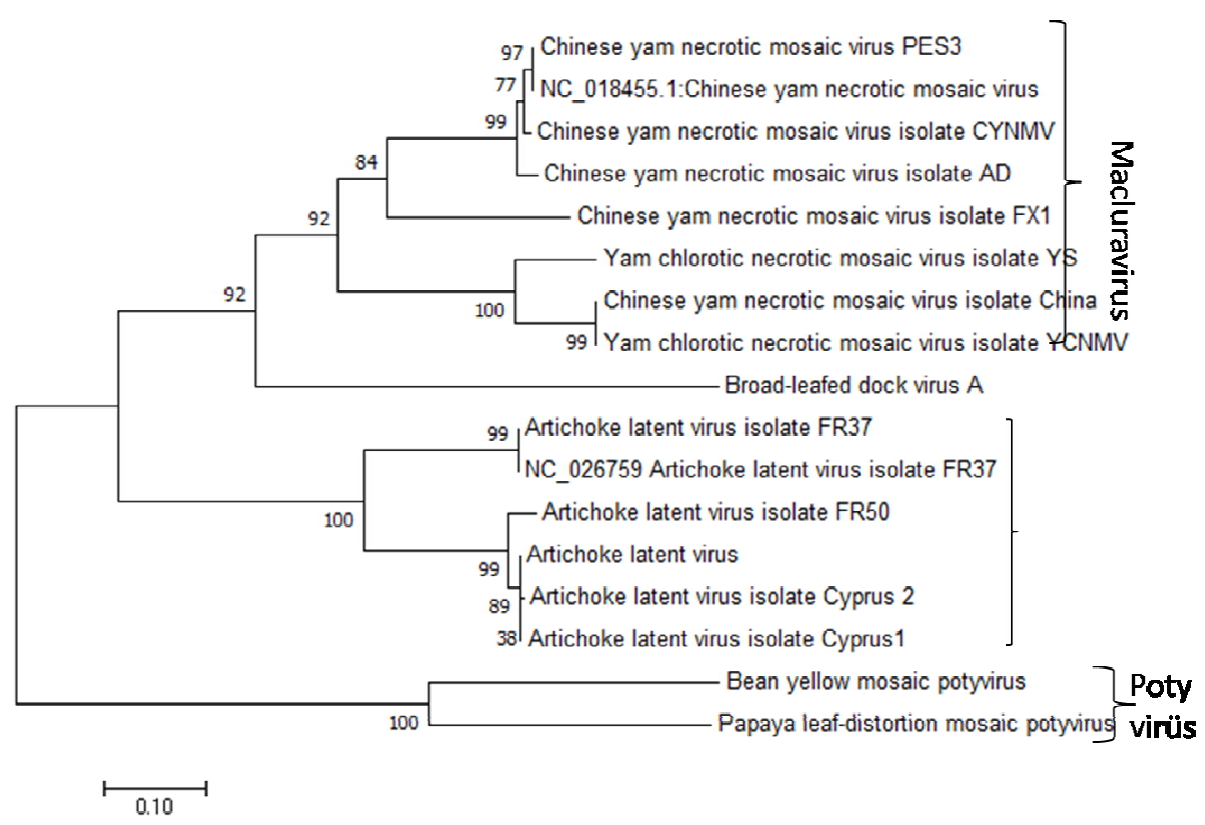

Figure 10. Phylogenetic tree of two different North Cyprus ARLV haplotypes which belong to Potyviridae and group of Macluravirus, had branched with same branch. While Macluraviruses clustered within intersection, Potyviruses have various subsets

\section{Discussion}

This investigation uncovered the characteristic conveyance and event of artichoke infections in territories situated in NC. Our outcomes called attention to the clean conditions for basic plant infections in growing fields in NC. ArLV and TSWV have the 
most across the board infections contaminating artichoke edits in NC. Genera Potyvirus and Tospovirus are transmitted by aphids and thrips separately. The board of these vectors are troublesome. The indications on gathered plants have seriously appointed to ArLV and TSWV by mixed contamination. These outcomes were fitted Testa et al. (2008) results where their Sardinian examples demonstrated a serious mosaic for the most part, and had ArLV mixed infection with Tomato spotted wilt virus (TSWV). The study was focused on ArLV due to first occurrence on artichoke. Although ArLV has a less host range than TSWV, the ArLV may survive in different weed species that are not having a place with the Asteraceae family filling in as a supply. These outcomes permit ArLV to be spread all the more continuously and to happen with high frequency, after essential contamination by infected seedling or inoculums sources. These results have confirmed Costa et al. (1959) results where it was reported that ArLV had isolated from symptomless artichoke plants in California. Severe systemic mosaics on Nicotiana clevelandii, necrotic local lesions on Chenopodium amaranticolor mechanically inoculated by ArLV Artichoke isolates gave identical symptoms which were confirmed by RT-PCR, previously recorded by Ciffou et al. (2011).

Previous studies have revealed artichoke latent virus found in Northern Cyprus and the Aegean region in Turkey (Fidan et al, 2015; Erkan et al., 2014). The current results have verified the previous results that artichoke plants infection with ArLV is limiting artichoke production in the Mediterranean basin as reported by other articles as well (Rana and Russo, 1980; Ortega et al., 2000). Also Minutillo et al. (2015) impressed that Ranunculus latent virus should be demonstrated as unique strain of ArLV. They also underlined that it is not a distinct species.

This is the first report of TSWV and ArLV + TSWV mix infection for artichoke in NC. This paper also indicates that uncontrolled distribution of infected artichoke plants in countries will create the viral problems. Molecular analyses have distinguished that there are two different ArLV haplotypes present in $\mathrm{NC}$ according to their sequence alignments in NCBI system. Although the Mediterranean Sea as a limiting factor separate the island from the mainland the same viral diseases occur on both places. In any case, sequence grouping arrangements have demonstrated NC's ArLV haplotypes are like Italian (KF155694.1 99)\% and French (KP405233.1 98\%) haplotypes showing all fare and import plant material can be disseminated without any quarantine direction. The NC is an important harbour in the Mediterranean Sea and all sort of business ships have been visiting for exchange (Lumia et al., 2003; Saitou and Nei, 1987; Tamura et al., 2007).

\section{Conclusion}

Further investigations ought to be gotten ready for recognizing individual vectors and obscure epidemiological highlights and qualities of the infections for instance potyviruses like ArLV which transmitted by aphids (Adams et al. , 2012). There are new virus infections sustaining in weeds and neighboring yield species in the Island. ArLV is the most severe of the 25 viruses recorded in Cynara scolymus L. and Cynara cardunculus L. from Europe and the Mediterranean. These viruses were having decreasing effectivity for the aspect of the productivity and the quality artichoke crop head (Gallitelli et al., 2012). The ArLV + TSWV mix infection in artichoke have synergistic effectivity and severity (Acquadro et al., 2010). Elbeaino et al. (2017) reported some artichoke viruses specially Artichoke Italian latent virus via Next 
Generation Sequencing technique and molecular analysis, focused on RNA1 and RNA2 sequences. Novel administration techniques for ailments will be formulated upon these examinations to ensure sanitized plants. Accordingly, the disease pathway and transmissibility of major infections could be counteracted.

Salleh et al. (2017) commented that Artichoke viruses could infect broad range of crop species and weeds as reservoir plants due to having potential for spreading by vectors. Also they mentioned the same viral factors could play important role in the ecology and viral epidemiology. Additionally, all verification, the use of inappropriate cuttings practices by farmers have critical point in same objections.

A certification programme for artichoke has become necessary. It is also indispensable for the globe artichoke biodiversity conservation. And breeding of virus free genetic resources is essential (Spanò et al., 2018). In order to block invasion of critical viruses which are potentially destructive for artichoke quarantine applications should be effectively applied in the island.

Acknowledgments. This work was supported by Virology Labs of Akdeniz University, Faculty of Agriculture, Plant Protection Department and Pozantı Vocational School of Çukurova University.

Conflict of interests. The authors declare that they have no conflict of interests.

Ethical approval. This article does not contain any studies with human participants or animals performed by any of the authors.

\section{REFERENCES}

[1] Acquadro, A., Papanice, M. A., Lanteri, S., Bottalico, G., Portis, E., Campanale, A., Finetti-Sialer, M. M., Mascia, T., Sumerano, P., Gallitelli, D. (2010): Production and fingerprinting of virus-free clones in a reflowering globe artichoke. - Plant Cell Tiss Organ Cult 100: 329-337.

[2] Adams, M. J., Zerbini, F. M., French, R., Rabenstein, F., Stenger, D. C., Valkonen, J. P. T. (2012): Family Potyviridae. - In: King, A. M. Q., Adams, M. J., Carstens, E. B., Lefkowitz, E. J. (eds.) Virus Taxonomy. Elsevier, San Diego, pp. 1069-1090.

[3] Adkins, S., Zitter, T., Momol, T. (2005): Tospoviruses (Family Bunyaviridae, Genus Tospovirus). - Institute of Food and Agricultural Sciences, University of Florida, Gainesville.

[4] Ciuffo, M., Testa, M., Lenzi, R., Turina, M. (2011): Ranunculus latent virus: a strain of artichoke latent virus or a new macluravirus infecting artichoke? - Arch Virol 156: 10531057.

[5] Clark, M. F., Adams, A. N. (1977): Characteristic of microplate method of enzymelinked immunosorbent assay for detection of plant viruses. - J. Gen. Virol. 34: 475-483.

[6] Costa, A. S., Duffus, J. E., Morton, D., Yarwood, C. E., Bardin, R. (1959): A latent virus of California artichokes. - Phytopathology 49: 49-53.

[7] Dellaporta, S. L., Wood, J., Hicks, J. B. (1983): A plant DNA mini-preparation: version 2. - Plant Mol Biol Rep. 1(4): 19-21. DOI: 10.1007/BF02712670.

[8] Erkan, S., Gümüş, M., Duman, İ., Paylan, İ. C., Ergün, M. (2014): The new report of artichoke latent virus (ArLV) from globe artichoke in Turkey. - Ege Üniv. Ziraat Fak. Derg. 51(3): 265-269.

[9] Elbeaino, T., Belghacem, I., Mascia, T., Gallitelli, D., Digiaro, M. (2017): Next generation sequencing and molecular analysis of artichoke Italian latent virus. - Arch Virol 162: 1805-1809. DOI: 10.1007/s00705-017-3290-8. 
[10] FAO (2015): Food and Agriculture Organization of the United Nations. The Statistics Division of FAO. - http://faostat.fao.org/.

[11] Fidan, H., Karanfiloğlu, H., Karamanl1, A., Kocadal, E., Baydar, K. (2015): A new virus disease, Artichoke Latent Virus Potyvirus (Arlv). - Artichoke Production Areas of NC. V. Plant Protection Congress, Antalya, Türkiye, 3-5 February 2015.

[12] Foddai, A., Marras, F. (1984): Influenza di ALV (Artichoke Latent Virus) sulla produttività del carciofo Spinoso Sardo. Considerazioni conclusive dopo un biennio di indagini. - Atti Giorn. Fitopat III: 353-358.

[13] Foddai, A., Manas, E., Idini, G. (1985): Indagine sulla reinfezione naturale del carciofo Spinoso Sardo risanato da ALV. - Informatore Fitopatologico 35: 57-58.

[14] Gallitelli, D., Rana, G. L., Vovlas, C., Martelli, G. P. (2004): Viruses of globe artichoke: an overview. - J. Plant Pathol. 86: 267-281.

[15] Gallitelli, D., Mascia, T., Martelli, G. P. (2012): Viruses in artichoke. - Advances in Virus Research 84: 289-324.

[16] Garland, S., Sharman, M., Persley, D., McGrath, D. (2005): The development of an improved PCR-based marker system for Sw-5, an important TSWV resistance gene of tomato. - Australian J. Agric. Research 56: 285-289.

[17] Lima, M. F., Carvalho, S. I. C., Ragassi, C. F., Bianchetti, L. B., Faleiro, F. G. Reifschneider, F. J. B. (2017): Characterization of a pepper collection (Capsicum frutescens L.) from Brazil Genet. - Mol. Res. 16(3): gmr16039704.

[18] Lumia, V., Pasquini, G., Barba, M. (2003): Sensitive detection of artichoke latent virus in globe artichoke field samples by onestep RT-PCR or tissue imprint hybridization. Journal of Phytopathology 151: 477-479.

[19] Manzanares, M. J. et al. (1995): Evaluation of globe artichoke and related germplasm for resistance to artichoke latent virus. - Euphytica 84: 219-228.

[20] Marrou, J., Mehani, S. (1964): Etude d'un virus parasite de l'artichaut. - Comptes Rendues de l'Académie d' Agriculture de France 50: 1051-1064.

[21] Martelli, G. P., Gallitelli, D. (2008): Viruses of Cynara. Characterization, Diagnosis and Management of Plant Viruses. Vol. 1. Industrial Crops. - Studium Press, Texas.

[22] Migliori, A., Homo, E., Corre, J., Marzin, H., Legal, V., Curvale, J. P. (1987): Repartition, fréquence et nuisibilité des virus chez l'artichaut en Bretagne. - PHM.-Revue Horticole 274: 29-36.

[23] Minutillo, S. A., Marais, A., Mascia, T., Faure, C., Svanella-Dumas, L., Theil, S. et al. (2015): Complete nucleotide sequence of artichoke latent virus shows it to be a member of the genus Macluravirus in the family Potyviridae. - Phytopathology 105: 1155-1160. DOI: 10.1094/PHYTO-01-15-0010-R.

[24] Ortega, A. M., Juarez, M., Armengol, J., Jorda, M. C. (2000): Viral diseases in artichoke crops in Spain. - Acta Hort. 681: 611-616.

[25] Pasquini, G., Barba, M. (2003): Evidence of viral infections in late artichoke cv. Romanesco. - Acta Hort. 681: 597-602.

[26] Paylan, I. C., Ergun, M., Erkan, S. (2013): First report of artichoke yellow ringspot virus in globe artichoke in Turkey. - Plant Disease 97(10): 1388-1388.

[27] Pecaut, P. (1994): Globe Artichoke. - In: Kalloo, G., Bergh, B. O. (eds.) Genetic Improvement of Vegetable Crops. Pergamon Press, Oxford, pp. 737-746.

[28] Pecaut, P., Dumas de Vaulx, R., Lof, H. (1983): Virus-free clones of globe artichoke (Cynara scolymus) obtained after in vitro propagation. - Acta Hortic 131: 303-309.

[29] Rana, G. L., Russo, M. (1980): Le virosi del carciofo in Italia: possibilita` di prevenzione e lotta. - Atti Giorn. Fitopatol. 2: 85- 93.

[30] Rana, G. L., Russo, M., Gallitelli, D., Martelli, G. P. (1982): Artichoke latent virus: characterization, ultrastructure, and geographical distribution. - Ann. App. Biol. 101: 279-289. 
[31] Rana, G. L., Elia, A., Nuzzaci, M., Lafortezza, R. (1992): Effects of artichoke latent virus infection on the production of artichoke heads. - Journal of Phytopathology 135: 153159. DOI: $10.1111 / \mathrm{j} .1439-0434.1992 . t b 01261 . x$.

[32] Saitou, N., Nei, M. (1987): The neighbor-joining method-a new method for reconstructing phylogenetic trees. - Mol Biol Evol 4: 406-425.

[33] Salleh, W., Minutillo, S. A., Spanò, R., Zammouri, S., Gallitelli, D., Mnari-Hattab, M. (2017): Occurrence of artichoke-infecting viruses in Tunisia. - EPPO Bull 47: 48-56. DOI: $10.1111 /$ epp. 12360 .

[34] Sambrook, J., Fritschi, E. F., Maniatis, T. (1989): Molecular Cloning: A Laboratory Manual. - Cold Spring Harbor Laboratory Press, New York.

[35] Spanò, R., Bottalico, G., Corrado, A., Campanale, A., Di Franco, A., Mascia, T. (2018): A protocol for producing virus-free artichoke genetic resources for conservation, breeding, and production. - Agriculture 8: 36 .

[36] Tamura, K., Peterson, D., Peterson, N., Stecher, G., Nei, M., Kumar, S. (2011): MEGA5: Molecular evolutionary genetics analysis using maximum likelihood, evolutionary distance and maximum parsimony methods. - Mol. Biol. Evol. 28: 2731-2739.

[37] Testa, M., Marras, P. M., Turina, M., Ciuffo, M. (2008): Resenza del virus dell'avvizzimento maculato del pomodoro (TSWV) su carciofo in Sardegna. - Protezione Delle Colture 2: 34-36. 